\title{
Organoleptic Test of Herbal Drinks From Family Medicinal Plants as Body Immunity in The Covid-19 Pandemic
}

\author{
${ }^{1}$ Mhd. Siddik Sinaga, ${ }^{2}$ Inayah Rizki Khaesarani, ${ }^{3}$ Sonya Liani Nasution, ${ }^{4}$ Jumatun Riskinandiya, ${ }^{5}$ Eliska \\ ${ }^{1234}$ Faculty of Tarbiyah and Teacher Training, State Islamic University of North Sumatra, Indonesia \\ ${ }^{5}$ Faculty of Public Health, State Islamic University of North Sumatra, Indonesia \\ Corresponding author: Mhd. Siddik Sinaga, e-mail: muhammadsiddiksinaga4200@gmail.com \\ Co-author : IRK: inayahrizki56@gmail.com, SLN: sonyaliani12@gmail.com \\ JR: jumatunrizkinandiya@gmail.com, EE: eliska@uinsu.ac.id
}

Submitted:25/08/2021 Revised: 16/09/2021 Accepted: 21/09/2021 Published online: 19/10/2021

DOI: https://doi.org/10.35308/j-kesmas.v7i2.4039 How to cite this article: Sinaga, M.S., Khaesarani, I.R., Nasution, S.L., Riskinandiya, J., \& Eliska. (2021). Organoleptic Test of Herbal Drinks From Family Medicinal Plants as Body Immunity in The Covid-19. J-Kesmas: Jurnal Fakultas Kesehatan Masyarakat (The Indonesian Journal of Public Health).8(2). 61-65.

\begin{abstract}
Family Medicinal Plants (FMP) have benefits and properties for the health of the body. However, this plant is only used as a kitchen spice alone without knowing other properties. Thus, then created an innovation or new product from the family medicinal plant. The goal is to find out the benefits of herbal beverage products through Organoleptic tests as the body's immunity during the Covid-19 pandemic for the people of Pulau Sejuk Village. This product is called Jakusema Herbal, which consists of ginger, turmeric, lemongrass, and honey. The research design uses a Pre-Experimental Design type One-Shot Case Study with nine panellists as research subjects. The study parameters used organoleptic and qualitative tests of vitamin $\mathrm{C}$ with potassium iodine (betadine) to see whether or not vitamin $\mathrm{C}$ was present in herbal beverage products. The results showed the best treatment was $\mathrm{P} 2$ treatment with consumer-preferred levels reaching: (1) colour 7,055>6,23 (2) texture 9,475>6,23, (3) taste 28,003>6,23, and (4) scent 7,617>6,23. Based on the results of organoleptic tests obtained that P2 treatment has a real influence on herbal beverage products. Furthermore, herbal beverage products were tested qualitatively. Then, $\mathrm{P} 2$ treatment has a higher vitamin $\mathrm{C}$ content than other treatments seen from discolouration in the product. Due to time constraints, vitamin $\mathrm{C}$ testing is only done qualitatively. It is recommended for further research using quantitative tests so that the data of research results are more detailed and accurate.
\end{abstract}

Keywords: Covid-19; Immunity; Organoleptic Test; Products; FMP.

\section{Introduction}

The problem of Covid-19 stems from a terrible event in March 2020 in Wuhan City, Hubei Province, China. This virus is a deadly disease and has never been indicated before in the human body (Putri, 2020). In spreading, this virus works so quickly that the potential for transmission is very high from humans to other humans. Currently, people affected by the Covid-19 virus do things like spit while bathing or sneezing in public without using a mask so that the virus has the potential to move around. In addition, the transmission of this virus attacks the vulnerable body so that humans who have weak body immunity are easier to get infected. Amalia (2020) explained that the Covid-19 virus seeks life opportunities in the human body as a place for their survival so that humans exposed to the Covid-19 virus experience a decrease in endurance. Thus, humans should maintain their immune systems to protect themselves from various viral diseases.

North Sumatra has 25 districts and eight cities. One of the districts in North Sumatra is Batu Bara Regency which has 100 villages. The village in question is the village of Pulau Sejuk, located in District Fifty (BPS
Sumut, 2020). This village is known for cultivating family medicinal plants used as a healing remedy for minor ailments, house decorations, and cooking spices. Most people in Pulau Sejuk are farmers' livelihoods by utilizing the land to grow family medicinal plants, such as ginger, turmeric, aloe vera, ginger, lemongrass, and others. This plant has many benefits, including improving immunity, fever drugs, diarrhoea drugs, warding off and inhibiting free radicals in the body, and so on (Yana, 2018). Thus, it can be said that family medicinal plants are helpful to keep the body's immunity stable to avoid the Covid-19 virus.

Based on the information obtained, almost every yard of the house is planted with family medicinal plants. Under these conditions, the government took the initiative to move the program to grow family medicinal plants on the agricultural land that has been provided. The government hopes that the community can utilize family medicinal plants as much as possible. One of the benefits is as a safe herbal medicine for the consumption of villagers. The utilization of this plant can maintain the endurance of the village community in the Covid-19 pandemic. However, the reality on the ground was much different than expected. This is because the 
people of Pulau Sejuk village only use family medicinal plants as kitchen ingredients, without knowing other properties.

Mr Waluyo, as Chairman of Dasawisma Pulau Sejuk Village, stated, "The problem that occurred in the community of Pulau Sejuk due to three main factors, namely (1) the lack of public understanding of the benefits of FMP plants as immunity in the pandemic Covid-19, (2) the lack of innovation of the village community Pulau Sejuk in the processing of FMP plants to the maximum, and (3) the community is still underestimated related to the processing of FMP plants into an innovation or new products that are more trending". From this information, it can be concluded that the low awareness of the village community of Pulau Sejuk has become one of the problems that must be adequately handled by the village government so that the community can accept the innovation of making products from family medicinal plants.

After analyzing the above problems, the researcher provides a creative and innovative solution to the problem faced. The solution is to develop a family medicinal plant into a herbal drink product called Jakusema Herbal. This product is a herbal beverage product whose manufacture is collaborated between family medicinal plants with honey where the FMP plant uses ginger, turmeric and lemongrass. This is done to see the benefits of family medicinal plants for the body's immunity in the Covid-19 pandemic. So, this product can be used as a product that prevents the spread of the Covid-19 virus.

This study used organoleptic tests as a measuring tool for consumer assessment of Jakusema Herbal beverage products. This product focuses on the benefits of immunity of the people of the Village of Pulau Sejuk. The goal is to discover the benefits of herbal beverage products through Organoleptic tests as immunity in the Covid-19 pandemic for the villagers of Pulau Sejuk, Batu Bara Regency, North Sumatra.

\section{Methods}

This research is experimental. The research uses a Pre-Experimental Designs type One-Shot Case Study where only one group is given treatment, and observations are carried out to see the results (Sugiyono $\&$ Mitha, 2020). From July 19 to August 19, 2021, this study was conducted in the Village Hall of Pulau Sejuk, Batu Bara Regency, to conduct Organoleptic test research on herbal drinks as body immunity during the Covid-19 pandemic. The research population is the village community of Pulau Sejuk, with a total of 14 people. Of the 14 people taken, nine people to be the subject of the study. Data collection is done through primary data and secondary data. Primary data is obtained from observations and interviews with panellists. Furthermore, secondary data is obtained from a variety of sources relevant to the topic discussed. The research instruments used questionnaires distributed to each panellist.

This study uses two data analyses: qualitative analysis and Complete Random Design (CRD) data analysis. Qualitative analysis is used to determine the presence or absence of vitamin $\mathrm{C}$ content in herbal drinks. In contrast, analysis of Complete Randomized Design (CRD) data is used to look at field designs in which all experimental units use only treatment and gal at. CRD is structured by 1 factor, namely Material Combination Factor $(\mathrm{P})$ :

1. $\mathrm{P} 0=2$ slices Ginger +2 pieces of turmeric $+1 / 4$ lemongrass stem $+1 / 2$ tablespoon honey $+100 \mathrm{ml}$ of water.

2. $P 1=3$ slices ginger +3 pieces of turmeric $+1 / 2$ lemongrass stem +1 tablespoon honey $+100 \mathrm{ml}$ of water.

3. $\mathrm{P} 2=5$ slices ginger +5 pieces of turmeric +1 stem of lemongrass +3 tablespoons of honey $+100 \mathrm{ml}$ of water.

The test is done once by producing three treatments. Suppose the experiment turns out that there is still a real difference in variance analysis (ANOVA). In that case, the next step is to test through the LSD test (Least Significance Different) with a fundamental level of $1 \%$ and the goal to find out the average value of each treatment of panellist assessment. The parameter used in this study is the Organoleptic test. Organoleptic tests help measure consumers' level of fondness for the colour, texture, taste, and scent of herbal beverage products. The consumer's preferred level testing method uses scoring methods to design numerical scales to make it easier for researchers to observe consumer favorability levels significantly.

Organoleptic test research and qualitative tests of vitamin $\mathrm{C}$ with potassium iodine (betadine) were conducted at the MAN Batu Bara IPA Laboratory. The process of making Jakusema Herbal Products is as follows: (1) Clean turmeric, red ginger, and lemongrass; (2) After that, slice turmeric as much as three sticks of turmeric, five slices of ginger, and one stem of lemongrass; (3) Put all slices of turmeric, red ginger, lemongrass, and mineral water as much as $100 \mathrm{ml}$ into a blender to smooth; (4) Next, strain the ingredients that have been tendered using a sieve and put it in a glass; (5) Pour three tablespoons of honey into the herbs that have been served in a glass and stir; (6) Finally, the herbs are ready to drink

\section{Results}

Organoleptic Test of Herbal Beverage Products 
Table 1. Average Value of Organoleptic Test of Herbal Drink Products in Pulau Sejuk Village, Batu Bara Regency, North Sumatra.

\begin{tabular}{ccccc}
\hline \multirow{2}{*}{ Treatment } & \multicolumn{4}{c}{ Average Value } \\
\cline { 2 - 5 } & Color & Texture & Taste & Scent \\
\hline P0 & $3 \mathrm{~b}$ & $2.1 \mathrm{~b}$ & $2.5 \mathrm{~b}$ & $1.1 \mathrm{a}$ \\
P1 & $2.2 \mathrm{~b}$ & $3 \mathrm{~b}$ & $2.8 \mathrm{~b}$ & $2 \mathrm{a}$ \\
P2 & $3.6 \mathrm{~b}$ & $4 \mathrm{~b}$ & $3.6 \mathrm{~b}$ & $3.1 \mathrm{a}$ \\
\hline
\end{tabular}

(Primary Data, 2021)
Based on Table 1. The colour assessment results of each panellist had the highest average value of organoleptic testing at $3.6 \mathrm{~b}$ and the lowest in P1 treatment at $2.2 \mathrm{~b}$. The texture assessment in this product is contained in the $\mathrm{P} 2$ treatment with the highest average value of $4 \mathrm{~b}$, and the lowest is in the $\mathrm{P} 0$ treatment of $2.1 \mathrm{~b}$. Then, the assessment on the highest taste was in the P2 treatment of 3.6b, and the lowest was in the P0 treatment of 2.5b. Meanwhile, for the assessment results on the highest scent, there is a P2 treatment of 3.1a, and the lowest is in the P0 treatment of 1.1a.

Table 2. Analysis of Variance of Organoleptic Test of Herbal Drink Products in Pulau Sejuk Village, Batu Bara Regency, North Sumatra.

\begin{tabular}{|c|c|c|c|c|c|c|c|c|c|c|}
\hline \multirow{2}{*}{ SK } & \multirow{2}{*}{ DB } & \multicolumn{2}{|c|}{ Colour } & \multicolumn{2}{|c|}{ Texture } & \multicolumn{2}{|c|}{ Taste } & \multicolumn{2}{|c|}{ Scent } & \multirow{2}{*}{$\begin{array}{c}\text { F Table } \\
(\mathbf{1 \%})\end{array}$} \\
\hline & & $\mathbf{J K}$ & KT & $\mathbf{J K}$ & KT & JK & KT & JK & KT & \\
\hline Sample & 2 & 9.371 & 4.685 & 18.074 & 9.037 & 16.074 & 8.037 & 5.851 & 2.925 & \multirow{4}{*}{6.23} \\
\hline Panelists & 8 & 4.927 & 0.616 & 6.518 & 0.81475 & 2.296 & 0.287 & 2.963 & 0.37 & \\
\hline Error & 16 & 10.629 & 0.664 & 15.26 & 0.95375 & 4.593 & 0.287 & 6.149 & 0.384 & \\
\hline \multirow[t]{2}{*}{ Total } & 26 & 24.927 & - & 39.852 & - & 39.852 & - & 14.963 & - & \\
\hline & & \multicolumn{2}{|c|}{ F Count $=7.055$} & \multicolumn{2}{|c|}{ F Count $=9.475$} & \multicolumn{2}{|c|}{ F Count $=28.003$} & \multicolumn{2}{|c|}{ F Count $=7.617$} & \\
\hline
\end{tabular}

\section{(Primary Data, 2021)}

Based on Table 2. It shows that the use of ginger, turmeric, lemongrass and honey in the 3rd treatment (P2) exerts a very noticeable influence on the colour, texture, taste and scent of herbal drink products. The analysis of variance shows that the F Count on colour (7.055), texture (9.475), taste (28.003), and scient
(7.617) is more significant than $\mathrm{F}$ Table (6.23). This means the assessment of colour, texture, taste, and scent on Jakusema Herbal products shows that panellists prefer the treatment $(\mathrm{P} 2)$ with five slices of ginger +5 pieces of turmeric +1 stem lemongrass +3 tablespoons of honey $+100 \mathrm{ml}$ of water.

\section{Qualitative Test of Vitamin C with Potassium Iodine (Betadine)}

Tabel 3. Qualitative Data on Vitamin C content in Herbal Beverage Products using Betadine Solution

\begin{tabular}{|c|c|c|c|c|}
\hline Num. & Treatment & Material Composition & $\begin{array}{l}\text { Preliminary } \\
\text { Color }\end{array}$ & $\begin{array}{c}\text { Ultimate Color } \\
\text { (Treatment }+ \text { Solution of } \\
\text { Potassium Iodide) }\end{array}$ \\
\hline 1 & P0 & $\begin{array}{l}2 \text { slices Ginger }+2 \text { pieces of turmeric }+1 / 4 \\
\text { lemongrass stem }+1 / 2 \text { tablespoon honey }+100 \mathrm{ml} \\
\text { of water. }\end{array}$ & Bright yellow & Light Brown \\
\hline 2 & $\mathrm{P} 1$ & $\begin{array}{l}3 \text { slices ginger }+3 \text { pieces of turmeric }+1 / 2 \\
\text { lemongrass stem }+1 \text { tablespoon honey }+100 \mathrm{ml} \\
\text { of water. }\end{array}$ & Pale yellow & Clear brown \\
\hline 3 & $\mathrm{P} 2$ & $\begin{array}{l}\text { Five slices ginger }+5 \text { pieces of turmeric }+1 \text { stem } \\
\text { of lemongrass }+3 \text { tablespoons of honey }+100 \mathrm{ml} \\
\text { of water. }\end{array}$ & Dark yellow & Clear yellow \\
\hline
\end{tabular}

(Primary Data, 2021)

Based on Table 3. Showed that the treatment of P2 with the composition of the ingredients, namely five slices of ginger +5 pieces of turmeric +1 stem of lemongrass +3 tablespoons of honey $+100 \mathrm{ml}$ of water, has a higher vitamin $\mathrm{C}$ content than another dossier when tested for vitamin $\mathrm{C}$ content with potassium iodine (betadine). This is seen from the discolouration produced by herbal drink products. Colour change from dark yellow to clear yellow.

\section{Discussion}

\section{Organoleptic Test of Herbal Drink Products}

The results of organoleptic tests obtained that Jakusema herbal products can be accepted for the villagers of Pulau Sejuk to be used as body immunity in 
the Covid-19 pandemic. Organoleptic test results have four criteria: colour, texture, taste, and scent, validated by panellists. In colour, obtained P2 treatment gives a real influence on the colour of herbal beverage products. The analysis of variance shows that $7.055>6.23$. This means that the colour assessment of herbal beverage products is more significant (7.055) than the value of $\propto$ $\mathbf{0 , 0 1}$ This is reinforced by the research of Lestari, which states that the unique colour of a product will give the main attraction to panellists to taste the product. The colour in herbal beverage products tends to be dark yellow. The yellow colour appears due to the presence of turmeric colour that dominates. In contrast, the resulting dark colour occurs because the colour of honey tends to dominate (Lestari, 2015). Like Winarto, turmeric is a yellow colouring substance for various food ingredients and the textile industry because turmeric contains a yellow pigment called curcuminoid (Winarto, 2019). Honey's dark colour is because honey contains many phonetic components (Evahelda et al., 2017).

The texture is essential sensing in influencing consumer acceptance of a product. This texture is usually related to the sense of touch or touch. Test results showed that the texture in herbal beverage products felt thick, sticky, fibrous, and diluted. Thick texture occurs because of the amount of honey given. Recent research explains that honey has many advantages, one of which is newly extracted honey has a thick texture (Aisyah, 2018). Based on table 2. above, ginger, turmeric, and lemongrass mixed with honey strongly influences the texture of herbal beverage products. Analysis of variance shows that 9,475>6,23. This means the panellist's assessment of the texture is more significant (9.475) compared to value $\boldsymbol{\alpha}=\mathbf{0 . 0 1}$.

The scent is a sense of smell that plays the organoleptic testing of a product produced. The scent is herbal drink products produces the aroma of lemongrass and honey. According to Siti, lemongrass plants have the main content that gives fresh scents such as lemons, called Cyril content (Aidah, 2020). In addition, according to Nayik \& Nanda, honey has useful indicators for consumers, including taste, colour, and aroma, because honey contains a substance called nectar substances. This has an impact on the increasing appetite for consumers who consume it regularly. In this case, what dominates in scent is lemongrass and honey that can give rise to appetite so that the body can balance between nutrients with nutrition (Nayik \& Nanda in Evahelda, et al., 2017). Based on table 2. above, the use of ginger, turmeric, and lemongrass mixed with honey greatly influences the aroma of herbal beverage products. Analysis of variance shows that $(7.617>6.23)$. This means that the panellists' assessment of scents is more significant (7.617) than the value of $\alpha=0.01$.

\section{Qualitative Test of Vitamin C with Potassium Iodide (Betadine)}

Qualitative tests of vitamin C with potassium iodide (betadine) are conducted to see whether or not vitamin $\mathrm{C}$ is present in herbal beverage products. Table 2 above shows that vitamin $\mathrm{C}$ content in $\mathrm{P} 2$ treatment is higher than in other treatments. This is seen from the change in the colour of the betadine solution to be brighter when the solution of potassium iodide (betadine) is mixed with herbal beverage products with the composition of P2 treatment ingredients, namely five slices of ginger + 5 pieces of turmeric +1 stem of lemongrass +3 tablespoons of honey $+100 \mathrm{ml}$ of water. Meanwhile, the lowest vitamin $\mathrm{C}$ content is found in $\mathrm{P} 0$. This can be seen from the moment the solution of potassium iodide (betadine) mixed with $\mathrm{P} 0$ shows a change in the colour of the solution faded and dark. This is because the raw materials in herbal beverage products contain high vitamin $\mathrm{C}$. The raw materials used are ginger, turmeric, lemongrass, and honey.

In ginger has a vitamin $\mathrm{C}$ content of $7.7 \mathrm{mg}$. Turmeric has a vitamin $\mathrm{C}$ content of $60 \mathrm{mg}$. Lemongrass has a vitamin $\mathrm{C}$ content of $2.6 \mathrm{mg}$, and honey contains vitamin $\mathrm{C}$ of $100 \mathrm{mg}$. Therefore, the more use of ginger, turmeric, lemongrass, and honey in herbal beverage products, the higher the vitamin $\mathrm{C}$ content in herbal beverage products. So, it was concluded that this product could be used as the body's immunity during the Covid-19 pandemic. Thus, the villagers of Pulau Sejuk can consume this herbal drink product to maintain the body's immune stability during the Covid-19 pandemic. Recent research shows vitamin $\mathrm{C}$ has antioxidants for the body that can accelerate improvement in Covid-19 cases. In addition, vitamin $\mathrm{C}$ can also be used as an antidote to free radicals and prevent oxidative stress by the deadly coronavirus. So, it is highly recommended to consume a lot of fruits and vegetables containing vitamin $\mathrm{C}$ during the Covid-19 pandemic to keep the human body's immunity stable (Armanto et al., 2020).

\section{Conclusion}

From the description above, then the best treatment in this study is the $\mathrm{P} 2$ treatment with the composition of the ingredients, namely five slices of ginger +5 pieces of turmeric +1 stem of lemongrass +3 tablespoons of honey $+100 \mathrm{ml}$ of water. Organoleptic test results state that P2 treatment can affect herbal beverage products very markedly and has the composition of consumer favourite levels reaching: (1) colour 7.055>6.23); (2) 
texture $(9.475>6.23)$; (3) taste $(28.003>6.23)$; and (4) scent $(7.617>6.23)$. Furthermore, for qualitative tests of vitamin $\mathrm{C}$ with potassium iodine (betadine) obtained, P2 treatment has a higher vitamin $\mathrm{C}$ content than other treatments. This can be seen from the discolouration in herbal beverage products from dark yellow to clear yellow. So it can be said that the $h_{1}$. The hypothesis is accepted in this herbal drink product after the organoleptic test and qualitative test of vitamin C. As a result, herbal beverage products can be received as immunity by the village community of Pulau Sejuk. Due to time constraints, vitamin $\mathrm{C}$ testing is only done qualitatively. It is recommended for further research using quantitative tests so that the data of research results are more detailed and accurate.

\section{Acknowledgement}

Thank you to the State Islamic University of North Sumatra and the KKN Dr-160 group, who have supported research funds. Also, to Mr Siswanto, S.PdI as the village head and the entire village community of Pulau Sejuk, Batu Bara Regency, North Sumatra, who had been willing to provide research location. Furthermore, the entire research team and field guidance lecturers have helped complete the research process, both in preparing proposals, data collection, data processing, and journal publication.

\section{Author Contribution}

The principal researcher is the first researcher whose role is to prepare ideas, arrange research proposals, determine research locations, determine research budgets as needed, process data, and make journals. Furthermore, the second researcher was a member of the researcher participating in editing and evaluating the shortcomings of journal results. In addition, the third and fourth researchers are members of the researchers who make herbal beverage products, from preparing all tools and ingredients to equipping herbal beverage products as needed by the study. Finally, the fifth researcher is a field guidance lecturer responsible for guiding and directing the entire series of research processes to the journal completion stage correctly and on time.

\section{References}

Aidah, Siti Nur \& Tim Penerbit KBM Indonesia. (2020). Ensiklopedia Serai Deskripsi, Filosofi, Manfaat, Budidaya, dan Peluang Bisinisnya. Jogjakarta: Karya Bakti Makmur Indonesia.

Aisyah, Noor. (2018). Analisis Kualitas Madu Yang Beredar Di Kota Semarang Berdasarkan Parameter Jenis, Indeks Bias, Dan Tegangan Permukaan. Skripsi: Fakultas Sains dan Teknologi, Universitas Islam Negeri Walisongo.

Amalia, L., Irwan, \& Hiola, F. (2020). Analisis Gejala Klinis Dan Peningkatan Kekebalan Tubuh Untuk Mencegah Penyakit Covid-19. Jambura Journal of Health Sciences and Research, 2(2), 71-76. https://doi.org/10.35971/jjhsr.v2i2.6134.

Armanto, et al. (2020). Pengaruh Vitamin C Terhadap Sistem Imun Tubuh Untuk Mencegah dan Terapi COVID-19. Molusca Medica. 12(2), 62-63. https://ojs3.unpatti.ac.id/index.php/moluccamedic a/article/download/2498/2313/.

Evahelda, E., et al. (2017). Sifat Fisik dan Kimia Madu Dari Nektar Pohon Karet di Kabupaten Bangka Tengah, Indonesia. AGRITECH. 37(4), 363-368. https://doi.org/10.22146/agritech.16424.

Lestari, Titiek Puji. (2015). Review: Sumber Dan Pemanfaatan Zat Warna Alam Untuk Keperluan Industri, Dinamika Kerajinan dan Batik. Jurnal, 2(2), 93-106. http://dx.doi.org/10.22322/dkb.v32i2.1365.

Profil Badan Pusat Statistik Provinsi Sumatera Utara. (2020). Medan: BPS Prov. Sumut.

Putri, Ririn Noviyanti. (2020). Indonesia Dalam Menghadapi Pandemi Covid-19. Jurnal Ilmiah Universitas Batangkari Jambi, 20(2), 705-709. http://dx.doi.org/10.33087/jiubj.v20i2.1010.

Sugiyono \& Erlisya, Mitha. (2020), Metode Penelitian Kesehatan. Bandung: Alfabeta CV.

Winarto, W. P. \& Tim Lentera. (2003). Khasiat \& Manfaat Kunyit. Jakarta: Agromedia Pustaka.

Yana. (2018). Study Jenis Rempah-Rempah dan Pemanfaatannya Di Pasar Tradisional Angso Duo. Skripsi: Fakultas Ilmu Tarbiyah dan Keguruan, Universitas Islam Negeri Sulthan Thaha Saifuddin Jambi. 